\title{
Effects of dietary conjugated linoleic acid on fatty acid composition and cholesterol content of hen egg yolks
}

\author{
Beata Szymczyk ${ }^{1}$ and Paweł M. Pisulewski ${ }^{2 \star}$ \\ ${ }^{1}$ Department of Animal Nutrition, Institute of Animal Production, 32-083 Balice, Poland \\ ${ }^{2}$ Department of Human Nutrition, Agricultural University of Cracow, al. 29 Listopada 46, 31-425 Kraków, Poland
}

(Received 13 June 2002 - Revised 11 February 2003 - Accepted 21 February 2003)

\begin{abstract}
The main objectives of the present study were to determine the effect of dietary conjugated linoleic acid (CLA) isomers on the fatty acid composition and cholesterol content of egg-yolk lipids. Forty-five 25 -week-old laying hens were randomly distributed into five groups of nine hens each and maintained in individual laying cages, throughout 12 weeks of the experiment. They were assigned to the five treatments that consisted of commercial layer diets containing $0,5,10,15$ or $20 \mathrm{~g}$ pure CLA $/ \mathrm{kg}$. Feed intake of hens varied little and insignificantly. Egg mass was uniformly lower $(P<0 \cdot 05)$ in the hens fed the CLA-enriched diets. Feed conversion efficiency, when expressed per kg eggs, was impaired $(P<0 \cdot 05)$, although without obvious relation to the dietary CLA concentration. Feeding the CLA-enriched diets resulted in gradually increasing deposition of CLA isomers $(P<0.01)$ in egg-yolk lipids. Saturated fatty acids were increased $(P<0.01)$ and monounsaturated fatty acids decreased $(P<0 \cdot 01)$. Polyunsaturated fatty acids (PUFA), when expressed as non-CLA PUFA, were also significantly decreased $(P<0 \cdot 01)$. The most striking effects $(P<0 \cdot 01)$ were observed for palmitic $(16: 0)$ and stearic $(18: 0)$ acids, which increased from 23.6 to $34 \%$ and from 7.8 to $18 \%$, respectively. On the other hand, oleic acid (18: $1 n-9)$ decreased from 45.8 to $24.3 \%$. Among non-CLA PUFA, linoleic $(18: 2 n-6)$ and $\alpha$-linolenic $(18: 3 n-3)$ acids were strongly $(P<0.01)$ decreased, from $14 \cdot 2$ to $7 \cdot 7 \%$ and from $1 \cdot 3$ to $0 \cdot 3 \%$, respectively. The same was true for arachidonic $(20: 4 n-6)$ and docosahexaenoic $(22: 6 n-3)$ acids. The cholesterol content of egg yolks, when expressed in $\mathrm{mg} / \mathrm{g}$ yolk, was not affected by the dietary CLA concentrations. In conclusion, unless the adverse effects of CLA feeding to laying hens on the fatty acid profile of egg yolks are eliminated, the CLA-enriched eggs cannot be considered functional food products.
\end{abstract}

Conjugated linoleic acid: Egg production: Fatty acid composition

The use of nutritional strategies to improve the composition and quality of food products of animal origin has emerged recently at the interface of animal science, food science and human nutrition. This new approach has been effectively used to alter product composition to be more consistent with human dietary guidelines. For example, feeding dairy cows with oil seeds, plant and fish oils, as rich sources of monounsaturated fatty acids (MUFA) and polyunsaturated fatty acids (PUFA), resulted in their subsequent incorporation into milk lipids (Kowalski et al. 1999; Goodridge et al. 2001). Equally, the dietary pattern of fatty acids was reproduced in carcass fat of beef cattle (Scollan et al. 2001), pigs (Wiseman \& Agunbiade, 1998; Matthews et al. 2000) and poultry (Leskanich \& Noble, 1997). Also egg-yolk lipids were easily enriched in dietary MUFA and PUFA (van Elswyk, 1997; Botsoglou et al. 1998; Ayerza \& Coates, 2001). Nutritionally modified butter (Noakes et al. 1996) or pork (Sandström et al. 2000; Stewart et al. 2001) or eggs (Lewis et al. 2000) decreased plasma cholesterol concentrations when consumed by human subjects.
Recently, there has been increased research on isomers of conjugated linoleic acid (CLA). CLA is a collective name referring to the positional and geometric (cis, trans) conjugated dienoic isomers of linoleic acid $(18: 2 n-6)$, present mainly in ruminant milk and meat (Fritche \& Steinhart, 1998; Lawson et al. 2001). The double bonds in CLA are usually either in C positions 9 and 11 or 10 and 12. Moreover, each of the double bonds can be in the cis or trans configuration. The CLA isomers have been shown to have health-promoting properties as components of animal diets. Of the major effects, evident anticarcinogenic and anti-atherogenic properties of CLA, and its ability to enhance immune responses in experimental animals were recently described (Roche et al. 2001). This has led to efforts to obtain CLA-enriched milk (Kelly et al. 1998; Dhiman et al. 1999; Baumgard et al. 2001), meat (Simon et al. 2000; Szymczyk et al. 2001; Joo et al. 2002) and eggs (Du et al. 2000; Jones et al. 2000) by nutritional means. Interestingly, CLAenriched butter has been demonstrated to reduce the number of chemically induced mammary tumours

Abbreviations: CLA, conjugated linoleic acid; MUFA, monounsaturated fatty acids; PUFA, polyunsaturated fatty acids; SFA, saturated fatty acids.

* Corresponding author: Professor Paweł M. Pisulewski, fax +48 1241177 53, email rrpisule@cyf-kr.edu.pl 
in female rats (Ip et al. 1999). Similarly, CLA-enriched egg yolks tended to induce hypocholesterolaemia in adult rats (Szymczyk \& Pisulewski, 2002).

Although direct extrapolation of the results from animal studies to man may be premature, it seems desirable to obtain and to evaluate CLA-enriched products as functional foods for human consumption. Therefore, the main objectives of the present study were to determine the effect of dietary CLA isomers on the fatty acid composition and cholesterol content of egg yolks.

\section{Material and methods}

Forty-five 25-week-old laying hens (Hy-Line Brown) were randomly distributed into five groups of nine hens each and maintained in individual laying cages, throughout 12 weeks of the experiment. They were assigned to the five treatments that consisted of modified Polish commercial layer diets ('DJ') containing $0,5,10,15$ or $20 \mathrm{~g}$ pure CLA $/ \mathrm{kg}$. The CLA source (Natural Lipids Ltd, Hovdebygda, Norway) contained $600 \mathrm{~g}$ CLA $/ \mathrm{kg}$. Appropriate amounts of sunflower-seed oil were included in the diets to equalise the total fat added to all diets at $50 \mathrm{~g} / \mathrm{kg}$ (Table 1). The fatty acid composition of the sunflower-seed oil and CLA supplement used in the present study is given in Table 2 . Feed and water were available ad libitum. All procedures involving animals were approved by the Animal Ethics Committee at the National Institute of Animal Production in Poland.

Individual feed intake was determined weekly. Eggs were collected daily, counted and weighed individually to obtain egg production and egg mass for the entire study. The rate of laying (egg production per 100 hens; \%) and feed conversion efficiency per one egg (feed intake per number of eggs; g) and per kg eggs (feed intake per egg mass; $\mathrm{kg}$ ) were calculated. In addition, eggs from each hen, collected every 4 weeks were broken, yolks were separated from albumen, weighed, and then frozen at $-20^{\circ} \mathrm{C}$ for further analyses.

On the day of analyses, the frozen yolks were thawed, mixed and then analysed for fatty acid composition and cholesterol content. Total egg-yolk lipids were extracted according to the method of Folch et al. (1957). They were saponified $\left(10 \mathrm{~min}, 75^{\circ} \mathrm{C}\right)$ in $0.5 \mathrm{M} \mathrm{KOH} / \mathrm{Me}-\mathrm{OH}$ and then methylated $\left(10 \mathrm{~min}, 75^{\circ} \mathrm{C}\right)$ in $14 \%(\mathrm{v} / \mathrm{v})$ $\mathrm{BF}_{3} / \mathrm{Me}-\mathrm{OH}$ (Morrison \& Smith, 1964). Finally, fatty acid methyl esters were extracted with hexane and analysed on a Hewlett-Packard (model 5890) gas chromatograph, equipped with a BPX 70 fused silica capillary column (length $50 \mathrm{~m} \times 0.22 \mathrm{~mm}$ internal diameter $\times 0.25$ $\mu \mathrm{m}$ film thickness; SGE International, Ringwood, Australia), and a flame ionisation detector. The carrier gas was He used at a split ratio of 50:1. The operating conditions were as follows: the temperature of the injector was $210^{\circ} \mathrm{C}$, and that of the detector was $240^{\circ} \mathrm{C}$. The initial oven temperature was $160^{\circ} \mathrm{C}$ for $35 \mathrm{~min}$, increasing progressively by $3{ }^{\circ} \mathrm{C} / \mathrm{min}$ to $210^{\circ} \mathrm{C}$, and held constant at $210^{\circ} \mathrm{C}$ for $10 \mathrm{~min}$. The fatty acid percentage was integrated and calculated using the Hewlett Packard ChemStation Computer Program (Palo Alto, CA). Fatty acid methyl esters were identified by comparison of their retention
Table 1. The ingredient composition and nutrient content of conjugated linoleic acid (CLA)-enriched experimental diets $(0,5,10$, 15 , and $20 \mathrm{~g} / \mathrm{kg}$ ) fed to laying hens

\begin{tabular}{|c|c|}
\hline \multicolumn{2}{|l|}{ Ingredients (g/kg) } \\
\hline Ground maize & 80 \\
\hline Ground wheat & 250 \\
\hline Ground barley & 280 \\
\hline Soyabean meal & 146 \\
\hline Rape & 40 \\
\hline Meat-and-bone meal & 40 \\
\hline Lucerne meal & 20 \\
\hline ver-seed oil* ${ }^{\star}$ & 50 \\
\hline Lime & 83 \\
\hline phate & $3 \cdot 0$ \\
\hline $\mathrm{NaCl}$ & 3.0 \\
\hline Mineral and vitamin premix $†$ & $5 \cdot 0$ \\
\hline \multicolumn{2}{|l|}{ Calculated nutrient content $(\mathrm{g} / \mathrm{kg})$} \\
\hline Metabolisable energy (MJ/kg & 11.59 \\
\hline & $167 \cdot 0$ \\
\hline Total $S$ amino acids & $6 \cdot 2$ \\
\hline Methionine & 3.5 \\
\hline Cys & $2 \cdot 7$ \\
\hline Lysi & 7.5 \\
\hline $\mathrm{Ca}$ & $35 \cdot 3$ \\
\hline P (available) & 3.4 \\
\hline Crude fibre & $42 \cdot 1$ \\
\hline \multicolumn{2}{|c|}{ 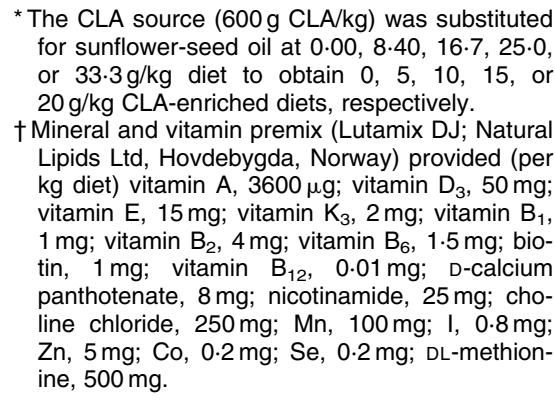 } \\
\hline
\end{tabular}

times with authentic standards purchased from SigmaAldrich (Poznan, Poland) and the CLA reference standards (9cis, 11trans, and 10trans, 12cis isomers) were obtained from Larodan Fine Chemicals AB (Malmö, Sweden). The above analyses were performed at the Meat and Fat Research Institute (Warsaw, Poland).

The total egg-yolk cholesterol was extracted according to the method of Folch et al. (1957) and determined enzymically (Allain et al. 1974) using commercial kits (Sigma-Aldrich).

The data were analysed using one-way ANOVA generated by the STATISTICA version 5.1 package (StatSoft, Tulsa, OK). Where appropriate, the Duncan's multiple range test (Duncan, 1955) was used to determine the significance of differences between treatment means at the $P<0.05$ and $P<0.01$ levels of significance.

\section{Results}

Feeding hens with graded amounts of dietary CLA $(0,5$, 10,15 , and $20 \mathrm{~g} / \mathrm{kg}$ diet) had no apparent effects on their production performance over the 12-week experimental period (Table 3). The overall means for feed intake 
Table 2. Fatty acid composition (relative \%) of sunflower-seed oil and conjugated linoleic acid (CLA) source fed to laying hens

\begin{tabular}{lcr}
\hline Fatty acid & Sunflower-seed oil & CLA \\
\hline $12: 0$ & - & $0 \cdot 1$ \\
$14: 0$ & $0 \cdot 01$ & $0 \cdot 1$ \\
$16: 0$ & $6 \cdot 2$ & $4 \cdot 9$ \\
$16: 1 n-7$ & - & $0 \cdot 1$ \\
$18: 0$ & - & $2 \cdot 0$ \\
$18: 1 n-9$ & $24 \cdot 4$ & $29 \cdot 9$ \\
$18: 1 n-7$ & - & $0 \cdot 7$ \\
$18: 2 n-6$ & $62 \cdot 9$ & $0 \cdot 5$ \\
CLA isomers & & \\
Total & - & $58 \cdot 7$ \\
Cis-9, trans-11 CLA & - & $9 \cdot 5$ \\
Trans-8, cis-10 CLA & - & $8 \cdot 6$ \\
Cis-11, trans-13 CLA & - & $9 \cdot 8$ \\
Trans-10, cis-12 CLA & - & $11 \cdot 2$ \\
Other CLA & - & $19 \cdot 6$ \\
$18: 3 n-3$ & $1 \cdot 0$ & - \\
$20: 0$ & $0 \cdot 3$ & 0.9 \\
$22: 0$ & $0 \cdot 6$ & $0 \cdot 3$ \\
$24: 0$ & $0 \cdot 2$ & $0 \cdot 1$ \\
Total fatty acids & $95 \cdot 6$ & $98 \cdot 3$ \\
& & \\
\hline
\end{tabular}

${ }^{*}$ CLA isomers were identified by double-bond positions from the carboxyl end and bond configurations (cis; trans).

of hens varied little and insignificantly. The hens fed the CLA-enriched diets $(5-20 \mathrm{~g} / \mathrm{kg})$ tended to have lower laying rates than those fed the control diet $(0 \mathrm{~g} / \mathrm{kg})$. Similarly, egg mass was uniformly lower $(P<0.05)$ in the hens fed the CLA-enriched diets. Feed conversion efficiency, when expressed per one egg, tended to decrease with increasing concentrations of dietary CLA. Conversely, when expressed per $\mathrm{kg}$ eggs, it was slightly increased $(P<0.05)$, although without obvious relation to the dietary CLA concentration.

The fatty acid composition of egg-yolk lipids, expressed as a percentage of total methyl esters of fatty acids, was significantly altered by increasing concentrations of dietary CLA (Table 4). The total and individual concentration of CLA isomers reached a maximum on week 4 and decreased slightly thereafter (Fig. 1). No CLA was found in the egg lipids of hens fed the control diet. In contrast, feeding the CLA-enriched diets resulted in increasing deposition of CLA isomers $(P<0.01)$. Interestingly, concentrations of individual CLA isomers in egg-yolk lipids did not entirely reflect those of the commercial CLA product, thus indicating preferential incorporation of these compounds. Generally, the relative proportions of cis-9, trans-11 and cis-11, trans-13 CLA isomers in egg-yolk lipids exceeded those found in the CLA product. On the other hand, trans-8, cis-10 and trans-10, cis-12 were incorporated into egg lipids less efficiently. The CLA-enriched diets significantly $(P<0 \cdot 01)$ increased the egg-yolk saturated fatty acid (SFA) concentrations and significantly $(P<0.01)$ decreased those of MUFA and non-CLA PUFA. Of individual SFA, the most striking effects $(P<0.01)$ were observed for $16: 0$ and 18:0, which increased from 23.6 to $34 \%$ and from 7.8 to $18 \%$, respectively. On the other hand, striking changes $(P<0.01)$ in concentrations of $18: 1 n-9$, which decreased from 45.8 to $24.3 \%$, produced overall decreases in MUFA concentrations. Among non-CLA PUFA, $18: 2 n-6$ and $18: 3 n-3$ concentrations were strongly $(P<0.01)$ reduced, from 14.2 to $7.7 \%$ and from 1.3 to $0.3 \%$, respectively. The same was true for $20: 4 n-6$ and $22: 6 n-3$. Concentrations of other non-CLA PUFA varied inconsistently.

The cholesterol content of egg yolks (Table 5), when expressed in $\mathrm{mg}$ per $\mathrm{g}$ yolk, was not affected by the increasing dietary CLA concentrations. Also, the reduction of egg cholesterol (mg per egg) became significant $(P<0.01)$ only as a result of reduction of egg yolk size.

\section{Discussion}

Overall, the production performance of laying hens (Table 3) was little affected by feeding CLA-enriched diets $(0,5,10,15$, and $20 \mathrm{~g} / \mathrm{kg}$ diet $)$. However, there were several apparent relationships between performance characteristics. Since the rate of laying (\%) was constant in hens fed the CLA-enriched diets and feed intake tended to be decreased by the $20 \mathrm{~g} / \mathrm{kg}$ CLA-enriched diet, the hens fed this diet required slightly less feed $(P>0.05)$ to produce one egg, as compared with the birds fed the other dietary treatments. On average, the feed intake and mass of eggs produced by hens fed

Table 3. Effect of feeding hens with conjugated linoleic acid (CLA)-enriched diets $(0,5,10,15$, and $20 \mathrm{~g} / \mathrm{kg})$ on their production characteristics during 12 weeks of experiment ${ }^{\star}$

(Mean values and standard errors of the mean)

\begin{tabular}{|c|c|c|c|c|c|c|c|c|c|c|}
\hline \multirow[b]{3}{*}{ Dietary level of CLA $(\mathrm{g} / \mathrm{kg})$} & & & & & \multirow{2}{*}{\multicolumn{2}{|c|}{$\begin{array}{l}\text { Feed intake } \\
\text { (g/hen per } d)\end{array}$}} & \multicolumn{4}{|c|}{ Feed conversion } \\
\hline & \multicolumn{2}{|c|}{ Rate of laying (\%) } & \multicolumn{2}{|c|}{ Egg mass (g) } & & & \multicolumn{2}{|c|}{ per egg (g) } & \multicolumn{2}{|c|}{ per kg eggs (kg) } \\
\hline & Mean & SEM & Mean & SEM & Mean & SEM & Mean & SEM & Mean & SEM \\
\hline 0 & $95 \cdot 2$ & 1.03 & $63 \cdot 7^{a}$ & 0.39 & $124 \cdot 0$ & $1 \cdot 77$ & $131 \cdot 2$ & 3.79 & $2 \cdot 07^{\mathrm{a}}$ & 0.05 \\
\hline 5 & $93 \cdot 1$ & 0.87 & $59 \cdot 7^{b}$ & 1.01 & $120 \cdot 0$ & 0.82 & $131 \cdot 0$ & 2.85 & $2 \cdot 19^{b}$ & 0.02 \\
\hline 10 & $93 \cdot 7$ & 1.39 & $61 \cdot 2^{b}$ & 0.47 & $126 \cdot 0$ & $2 \cdot 04$ & $130 \cdot 7$ & $1 \cdot 84$ & $2 \cdot 13^{a b}$ & 0.01 \\
\hline 15 & $93 \cdot 8$ & $1 \cdot 29$ & $61 \cdot 2^{b}$ & 0.22 & $123 \cdot 0$ & 1.03 & $130 \cdot 5$ & 1.55 & $2 \cdot 14^{a b}$ & 0.02 \\
\hline 20 & $93 \cdot 0$ & 0.67 & $60 \cdot 6^{b}$ & 0.65 & $119 \cdot 2$ & 0.85 & $128 \cdot 7$ & $1 \cdot 18$ & $2 \cdot 12^{a b}$ & 0.04 \\
\hline
\end{tabular}

a,b Mean values within a column with unlike superscript letters were significantly different $(P \leq 0.05$; analysed by Duncan's multiple range test).

${ }^{*}$ For details of diets and procedures, see Tables 1 and 2 and p. 94 
Table 4. Effect of feeding hens with conjugated linoleic acid (CLA)-enriched diets $(0,5,10,15$, and $20 \mathrm{~g} / \mathrm{kg}$ ) on fatty acid composition (relative $\%)$ of egg-yolk lipids after 4 weeks of experiment ${ }^{\star}$

(Mean values and standard errors of the mean)

\begin{tabular}{|c|c|c|c|c|c|c|c|c|c|c|c|c|}
\hline \multirow[b]{3}{*}{ Fatty acids } & & & \multicolumn{10}{|c|}{ Dietary level of CLA $(\mathrm{g} / \mathrm{kg})$} \\
\hline & \multicolumn{2}{|c|}{$\begin{array}{c}\text { Pre- } \\
\text { experimental }\end{array}$} & \multicolumn{2}{|c|}{0} & \multicolumn{2}{|c|}{5} & \multicolumn{2}{|c|}{10} & \multicolumn{2}{|c|}{15} & \multicolumn{2}{|c|}{20} \\
\hline & Mean & SEM & Mean & SEM & Mean & SEM & Mean & SEM & Mean & SEM & Mean & SEM \\
\hline $14: 0$ & 0.3 & 0.01 & $0.3^{a}$ & 0.02 & $0.5^{b}$ & 0.02 & $0.6^{\mathrm{bc}}$ & 0.04 & $0 \cdot 7^{c}$ & 0.04 & $0.7^{c}$ & 0.02 \\
\hline $16: 0$ & 24.4 & 0.12 & $23 \cdot 6^{\mathrm{a}}$ & 0.27 & $29 \cdot 6^{\mathrm{b}}$ & 0.78 & $30 \cdot 3^{\mathrm{b}}$ & 0.22 & $33 \cdot 1^{\mathrm{c}}$ & 0.93 & $34 \cdot 0^{\mathrm{C}}$ & 0.69 \\
\hline $16: 1 n-7$ & 2.6 & 0.08 & $2 \cdot 2^{\mathrm{a}}$ & 0.13 & $1.5^{\mathrm{b}}$ & 0.07 & $1 \cdot 1^{\mathrm{c}}$ & 0.04 & $1 \cdot 1^{\mathrm{c}}$ & 0.1 & $1 \cdot 2^{\mathrm{bc}}$ & 0.02 \\
\hline $17: 0$ & 0.2 & 0.00 & $0 \cdot 2^{\mathrm{a}}$ & 0.00 & $0.3^{b}$ & 0.04 & $0.3^{\mathrm{b}}$ & 0.00 & $0.3^{\mathrm{b}}$ & 0.02 & $0.3^{\mathrm{b}}$ & 0.00 \\
\hline $18: 0$ & 7.9 & 0.16 & $7 \cdot 8^{\mathrm{a}}$ & 0.23 & $14 \cdot 6^{\mathrm{b}}$ & 0.26 & $17 \cdot 6^{\mathrm{c}}$ & 0.50 & $18 \cdot 7^{\mathrm{C}}$ & 0.94 & $18 \cdot 0^{c}$ & 0.33 \\
\hline $18: 1 n-9$ & 45.9 & 0.34 & $45 \cdot 8^{\mathrm{a}}$ & 0.42 & $30 \cdot 3^{b}$ & 0.54 & $26 \cdot 3^{c}$ & 0.20 & $23 \cdot 2^{\mathrm{cd}}$ & 0.75 & $24.3^{\text {cd }}$ & 0.50 \\
\hline $18: 2 n-6$ & $12 \cdot 3$ & 0.28 & $14 \cdot 2^{\mathrm{a}}$ & 0.34 & $13 \cdot 8^{\mathrm{b}}$ & 0.55 & $12 \cdot 9^{\mathrm{ab}}$ & 0.27 & $11 \cdot 1^{\mathrm{b}}$ & 0.55 & $7 \cdot 7^{\mathrm{c}}$ & 0.23 \\
\hline $18: 3 n-3$ & 1.5 & 0.01 & $1 \cdot 3^{\mathrm{a}}$ & 0.04 & $1.3^{\mathrm{b}}$ & 0.05 & $0.9^{\mathrm{b}}$ & 0.02 & $0.3^{c}$ & 0.02 & $0.3^{c}$ & 0.00 \\
\hline $20: 1 n-9$ & 0.2 & 0.00 & $0.2^{\mathrm{a}}$ & 0.02 & $0.3^{\mathrm{b}}$ & 0.00 & $0.3^{\mathrm{b}}$ & 0.02 & $0.4^{\mathrm{c}}$ & 0.00 & $0.5^{\mathrm{c}}$ & 0.00 \\
\hline $20: 4 n-6$ & 1.9 & 0.04 & $1.6^{\mathrm{a}}$ & 0.06 & $1 \cdot 3^{\mathrm{ab}}$ & 0.06 & $1 \cdot 2^{\mathrm{abc}}$ & 0.04 & $1 \cdot 1^{\mathrm{c}}$ & 0.04 & $0 \cdot 8^{d}$ & 0.04 \\
\hline $22: 5 n-3$ & 0.1 & 0.00 & $0.1^{\mathrm{a}}$ & 0.00 & $0.3^{b}$ & 0.00 & $0.3^{\mathrm{b}}$ & 0.02 & $0 \cdot 3^{b}$ & 0.00 & $0 \cdot 1^{\mathrm{a}}$ & 0.00 \\
\hline $22: 6 n-3$ & 0.7 & 0.02 & $1.4^{\mathrm{a}}$ & 0.06 & $1.0^{\mathrm{b}}$ & 0.02 & $0.6^{\mathrm{c}}$ & 0.04 & $0.3^{\mathrm{d}}$ & 0.00 & $0.2^{d}$ & 0.02 \\
\hline \multicolumn{13}{|l|}{ CLA isomers } \\
\hline Cis-9, trans-11 & 0.0 & 0.00 & $0 \cdot 0^{\mathrm{a}}$ & 0.00 & $0.7^{b}$ & 0.02 & $1.4^{\mathrm{C}}$ & 0.05 & $1.9^{d}$ & 0.02 & $2 \cdot 5^{\mathrm{e}}$ & 0.02 \\
\hline Trans- 8 , cis-10 & 0.0 & 0.00 & $0.0^{\mathrm{a}}$ & 0.00 & $0.3^{b}$ & 0.02 & $0.5^{\mathrm{c}}$ & 0.00 & $0.6^{c}$ & 0.00 & $0 \cdot 8^{d}$ & 0.04 \\
\hline Cis-11, trans-13 & 0.0 & 0.00 & $0.0^{\mathrm{a}}$ & 0.00 & $0.5^{\mathrm{b}}$ & 0.02 & $1.0^{c}$ & 0.02 & $1.4^{\mathrm{d}}$ & 0.04 & $1 \cdot 8^{\mathrm{e}}$ & 0.06 \\
\hline Trans-10, cis-12 & 0.0 & 0.00 & $0.0^{\mathrm{a}}$ & 0.00 & $0.3^{b}$ & 0.02 & $0.6^{\mathrm{c}}$ & 0.02 & $0.9^{d}$ & 0.02 & $1.3^{\mathrm{e}}$ & 0.04 \\
\hline Other CLA isomers & 0.0 & 0.00 & $0.0^{\mathrm{a}}$ & 0.00 & $0.5^{\mathrm{b}}$ & 0.00 & $1.0^{\mathrm{b}}$ & 0.06 & $1 \cdot 6^{\mathrm{c}}$ & 0.07 & $2 \cdot 0^{\mathrm{d}}$ & 0.09 \\
\hline Total SFA & $32 \cdot 8$ & 0.30 & $31 \cdot 0^{\mathrm{a}}$ & 0.35 & $45 \cdot 2^{b}$ & 1.20 & $49 \cdot 1^{c}$ & 0.45 & $53 \cdot 1^{d}$ & 0.93 & $53 \cdot 3^{d}$ & 1.50 \\
\hline Total MUFA & $48 \cdot 7$ & 0.68 & $49 \cdot 1^{\mathrm{a}}$ & 0.87 & $33 \cdot 6^{\mathrm{b}}$ & 1.41 & $29 \cdot 1^{b c}$ & 0.54 & $26 \cdot 0^{\mathrm{c}}$ & 0.81 & $28 \cdot 1^{\text {bc }}$ & 0.54 \\
\hline Non-CLA PUFA & $18 \cdot 4$ & 0.21 & $19 \cdot 3^{\mathrm{a}}$ & 0.36 & $18 \cdot 6^{\mathrm{b}}$ & 0.34 & $16 \cdot 4^{c}$ & 0.38 & $13 \cdot 9^{d}$ & 0.27 & $9.9^{\mathrm{e}}$ & 0.43 \\
\hline
\end{tabular}

SFA, saturated fatty acids; MUFA, monounsaturated fatty acids; PUFA, polyunsaturated fatty acids.

$\mathrm{a}, \mathrm{b}, \mathrm{c}, \mathrm{d}, \mathrm{e}$ Mean values for CLA dietary level effect within a row with unlike superscript letters were significantly different $(P \leq 0 \cdot 01$; analysed by Duncan's multiple range test).

${ }^{*}$ For details of diets and procedures see Tables 1 and 2 and p. 94.

the CLA-enriched diets were lower $(P>0.05$ and $P<0.05$, respectively) than those recorded for the control group. Thus, since the mass of eggs was more affected by dietary CLA, the resulting average feed conversion efficiency, when expressed as $\mathrm{kg}$ of feed required per $\mathrm{kg}$ eggs produced, was higher $(P<0.05)$ in the hens fed the CLAenriched diets than in those fed the control diet. Our results partly correspond to those associated with much higher

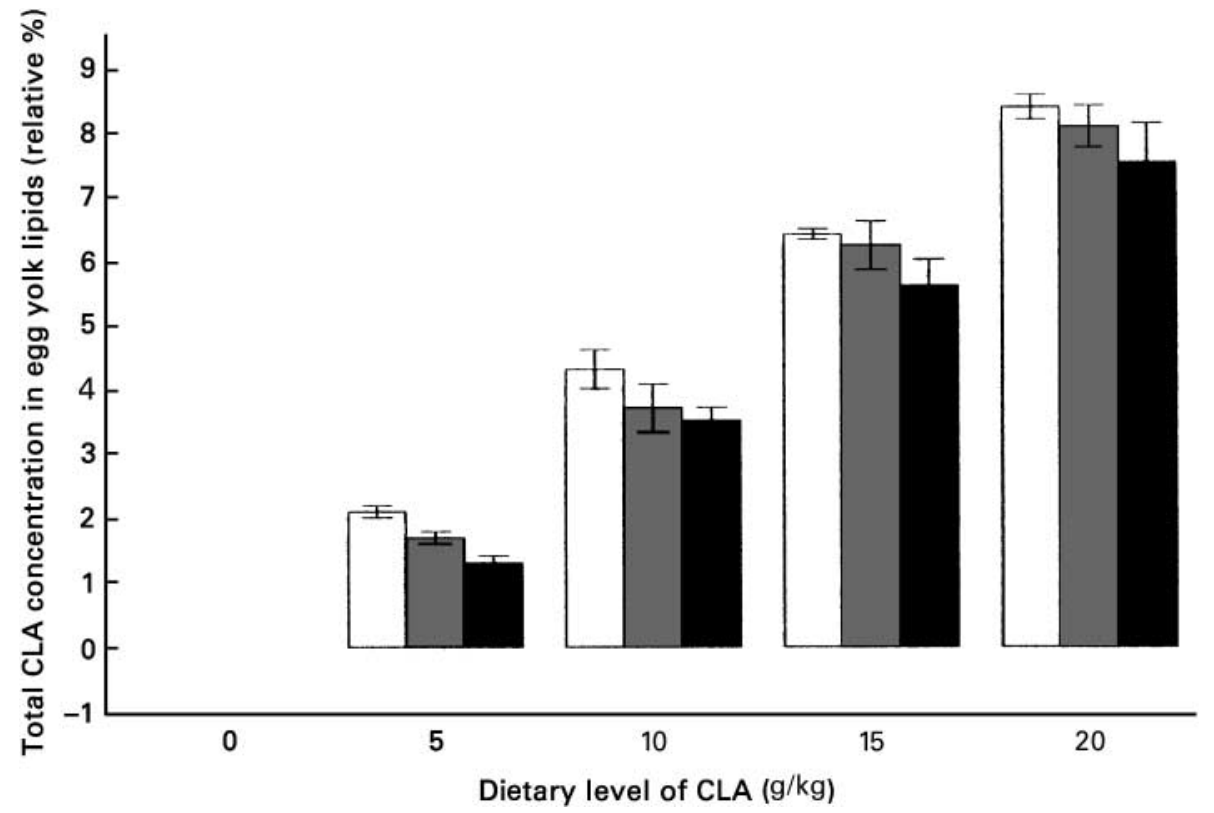

Fig. 1. Effect of feeding conjugated linoleic acid (CLA)-enriched diets to laying hens on the total concentration of CLA isomers in egg-yolk lipids at week $4(\square)$, week $8(\square)$ and week $12(\square)$ of the experiment. Values are means, with standard errors of the mean represented by vertical bars. 
Table 5. Effect of feeding laying hens with conjugated linoleic acid (CLA)-enriched diets $(0,5,10,15$, and $20 \mathrm{~g} / \mathrm{kg}$ ) on egg cholesterol content ( $\mathrm{mg} / \mathrm{g}$ of yolk and $\mathrm{mg} / \mathrm{egg}$ ) during 12 weeks of experiment*

(Mean values and standard errors of the mean)

\begin{tabular}{|c|c|c|c|c|c|c|}
\hline \multirow[b]{3}{*}{ Dietary level of CLA $(\mathrm{g} / \mathrm{kg})$} & & & \multicolumn{4}{|c|}{ Cholesterol content } \\
\hline & \multicolumn{2}{|c|}{ Weight of yolk (g) } & \multicolumn{2}{|c|}{$\mathrm{mg} / \mathrm{g}$ yolk } & \multicolumn{2}{|c|}{$\mathrm{mg} / \mathrm{egg}$} \\
\hline & Mean & SEM & Mean & SEM & Mean & SEM \\
\hline 0 & $17 \cdot 22$ & 0.31 & $15 \cdot 24$ & 0.62 & $262 \cdot 43^{\mathrm{a}}$ & 4.55 \\
\hline 5 & 16.58 & 0.28 & 14.49 & 0.64 & $240 \cdot 24^{b}$ & 3.82 \\
\hline 10 & $16 \cdot 73$ & 0.23 & 14.28 & 0.70 & $238.90^{\mathrm{b}}$ & 4.02 \\
\hline 15 & 16.42 & 0.33 & 14.09 & 0.59 & $231.35^{\mathrm{bc}}$ & 3.68 \\
\hline 20 & 16.93 & 0.26 & 13.47 & 0.65 & $228.05^{c}$ & 3.80 \\
\hline
\end{tabular}

${ }^{a, b, c}$ Mean values within a column with unlike superscript letters were significantly different $(P \leq 0.01$; analysed by Duncan's multiple range test).

${ }^{*}$ For details of diets and procedures see Tables 1 and 2 and p. 94.

concentrations of dietary CLA. For example, feeding laying hens with a diet containing $50 \mathrm{~g}$ CLA $/ \mathrm{kg}$ (Ahn et al. 1999) adversely affected feed intake and the rate of laying, whereas no effect on egg mass was detected. The results of two separate experiments, using hens fed the $50 \mathrm{~g} / \mathrm{kg}$ CLA-enriched diets (Chamruspollert \& Sell, 1999), were contradictory. In the first experiment, feed intake and the rate of laying were not affected and egg mass was decreased, whereas in the second one, feed intake was decreased but neither the rate of laying nor egg mass were affected. Alternatively, feeding laying hens with relatively low concentrations of dietary CLA $(10 \mathrm{~g} / \mathrm{kg})$ had no adverse effects on the rate of laying, feed intake, nor egg mass (Raes et al. 2002). On the other hand, as reported by Jones et al. (2000), the rate of laying was significantly decreased $(P<0.05)$ in hens fed diets enriched in even lower concentrations of CLA $(0 \cdot 0$, $0 \cdot 1,5 \cdot 0$, and $10 \cdot 0 \mathrm{~g} / \mathrm{kg}$ ). In addition, the birds of the CLA-fed groups $(0.1$ and $10.0 \mathrm{~g}$ CLA $/ \mathrm{kg})$ consumed slightly less feed, relative to body mass, than birds of the control and $5 \mathrm{~g} / \mathrm{kg}$ CLA group, over the entire study. At the same time, no significant differences between treatments were observed for egg mass. The data reported earlier might indicate that the concentration of dietary CLA is not the only factor affecting production performance of laying hens.

The finding that the amounts of CLA isomers incorporated into egg-yolk lipids were proportional to the levels of CLA in the diet (Table 4) was the major feature of the present study. It was also found (Fig. 1) that the concentrations of total CLA isomers in egg-yolk lipids reached their maximum after the first 4-week period. From a physiological point of view, the period of $10-14 \mathrm{~d}$ seems to be sufficient to obtain maximum incorporation of CLA isomers into egg-yolk lipids (Chamruspollert \& Sell, 1999; $\mathrm{Du}$ et al. 1999; Jones et al. 2000; Aydin et al. 2001; Raes et al. 2002). Moreover, we found that cis-9, trans11 and cis-11, trans-13 were incorporated into egg-yolk lipids preferentially, when compared with trans-8, cis-10 and trans-10, cis-12 isomers. This also confirms earlier findings of Du et al. (1999), Jones et al. (2000) and, more recently, Raes et al. (2002). The preferential incorporation of CLA isomers into tissue lipids was also observed in our experiments with rats (Szymczyk et al.
2000) and broilers (Szymczyk et al. 2001) fed CLAenriched diets. This may be because trans-10, cis-12 CLA appears to be metabolised more efficiently than cis-9, trans-11, at least in mice (Park et al. 1999).

As compared with the fatty acid composition of egg-yolk lipids produced by the control group, the proportions of SFA were increased $(P<0.01)$ with increasing dietary CLA concentrations, whereas those of MUFA decreased $(P<0 \cdot 01)$. The earlier findings can be related to the inhibitory effect of CLA isomers on the liver $\Delta 9$-desaturase (stearoyl-CoA desaturase), the enzyme that catalyses the insertion of a double bond between $\mathrm{C}_{9}$ and $\mathrm{C}_{10}$ atoms of either 16:0 or 18:0 (Cook, 1991). More recently it was shown that CLA inhibited stearoyl-CoA desaturase mRNA expression (Lee et al. 1998). Hence, it has been demonstrated (Table 4) that relative concentrations of $16: 0$ and $18: 0$ in egg-yolk lipids were increased, whereas those of $16: 1 n-7$ and $18: 1 n-9$ decreased significantly in hens fed CLA-enriched diets. These changes have been already reported for egg-yolk lipids of hens fed CLAenriched diets. (Ahn et al. 1999; Chamruspollert et al. 1999; Du et al. 1999; Raes et al. 2002). The same was true for tissue lipids of rats (Szymczyk et al. 2000), broilers (Simon et al. 2000; Szymczyk et al. 2001), and pigs (Ramsay et al. 2001). These effects may be of concern since the increasing degree of saturation of egg-yolk lipids affects negatively the quality of eggs (Ahn et al. 1999; Aydin et al. 2001) and causes $100 \%$ embryonic mortality in the fertile eggs (Aydin et al. 2001).

Significant decreases in the relative concentrations of non-CLA PUFA (Table 4), mainly $18: 2 n-6$ and $18: 3 n-3$ and their derivatives $(20: 4 n-6$ and $22: 6 n-3$, respectively) in egg-yolk lipids, could be related to substituting the CLA oil for sunflower-seed oil (a source of $18: 2 n-6$ and $18: 3 n-3$; Table 2). Similar effects of replacing soyabean oil with a CLA source in diets fed to hens were reported by Ahn et al. (1999), Chamruspollert \& Sell (1999), and Du et al. $(1999,2000)$. Also, the changes in concentrations of $20: 4 n-6$ and $22: 6 n-3$ in egg-yolk lipids could have resulted from inhibitory effects of CLA isomers on the metabolism of $18: 2 n-6$ and $18: 3 n-3$ series of fatty acids in laying hens. Indeed, it was found that that CLA isomers may compete with both $18: 2 n-6$ and $18: 3 n-3$ for $\Delta 6$-desaturase, the rate-limiting enzyme for the conversion of these 
fatty acids to $20: 4 n-6$ and $22: 6 n-3$, at least in mouse liver microsomes (Belury \& Kempa-Steczko, 1997). Moreover, it was reported that this effect was attributed to the cis-9, trans-11 CLA isomer (Bretillon et al. 1999).

The cholesterol content of eggs (Table 5), when expressed either in $\mathrm{mg}$ per $\mathrm{g}$ yolk or $\mathrm{mg}$ per egg, was not, in fact, affected by the increasing dietary CLA concentrations. The reduction of egg cholesterol, expressed in terms of mg per egg, was only apparent and became significant $(P<0.01)$ as a result of reduction of egg yolk size. Therefore it can be clearly stated that for the 12week period of our experiment, dietary CLA did not change cholesterol concentration in hen egg yolks.

The reported increases in concentrations of SFA and parallel decreases in concentrations of both MUFA and PUFA ( $n-6$ and $n-3)$ in egg-yolk lipids (Table 4) may be seen as undesirable for consumers. Namely, increased SFA consumption is associated with hypercholesterolaemia and the risk of CHD (Schaefer, 2002). Also, the overall data indicate that PUFA are hypocholesterolaemic and/ or anti-atherogenic. Specifically, high intakes of $n-3$ PUFA are beneficial and associated with lower platelet aggregation, lower immune response, and lower systolic and diastolic blood pressure (Mantzioris et al. 2000; Schaefer, 2002). Interestingly, the commonly reported adverse effects of dietary CLA on fatty acid composition of eggyolk lipids may be prevented by nutritional manipulation. Thus, olive oil (a rich source of $18: 1 n-9$ ) fed to laying hens prevented CLA-induced increases in 16:0 and $18: 0$ and the decrease in $18: 1 n-9$ in egg-yolk lipids (Aydin et al. 2001). However, feeding olive oil resulted also in considerably lower incorporation of CLA isomers into egg-yolk lipids (Aydin et al. 2001). In a similar approach, feeding laying hens with CLA-supplemented, $\alpha$-linolenic acid-rich diets resulted in increased accumulation of $n$-3 PUFA, i.e. $18: 3 n-3,20: 5 n-3$ and $22: 6 n-3$ (Du et al.2000). Less consistently, when an excess of dietary $18: 3 n-3$ was fed, the amounts of $18: 3 n-3$ and $20: 5 n$ 3 in egg-yolk lipids were decreased and those of $22: 5 n-3$ and 22:6n-3 increased, as found by Raes et al. (2002). Thus, feeding plant oils rich in 18:3n-3 (for example, flaxseed oil) to laying hens seems to be a promising means to eliminate, at least partly, the adverse effects of CLA on fatty acid composition ( $n-3$ series) of egg-yolk lipids.

From a nutritional point of view, the egg is considered an ideal target for dietary modification leading to the development of a functional food. The benefits of improving the quality of eggs by enhancing the concentrations of n-3 fatty acids, vitamin E, carotenoids, and Se were reported by Surai \& Sparks (2001). The same may be true for CLA as a novel functional component with evident cardio-protective properties in human subjects, as reported recently by Noone et al. (2002). However, unless the several adverse effects of feeding CLA to laying hens on the fatty acid profile of egg yolks are eliminated, the CLAenriched eggs cannot be considered functional food products in human nutrition. Further investigation is certainly needed to determine conclusively the efficient nutritional strategy for the production of CLA-enriched eggs with acceptable fatty acid composition and sensory properties.

\section{Acknowledgements}

The authors wish to thank Professor Jan Wadstein (Natural Lipids Ltd, Hovdebygda, Norway) for providing the CLA supplement and Professor Mieczysław Obiedzinski (Meat and Fat Research Institute, Warsaw, Poland) for analyses of egg-yolk lipids. This work was supported by the State Committee for Scientific Research, research grant no. 5-P06E-021-15.

\section{References}

Ahn DU, Sell JL, Jo C, Chamruspollert M \& Jeffrey M (1999) Effect of dietary conjugated linoleic acid on the quality characteristics of chicken eggs during refrigerated storage. Poult Sci 78, 922-928.

Allain CC, Poon LS, Chan CS, Richmind W \& Fu PC (1974) Enzymatic determination of total serum cholesterol. Clin Chem 20, 470-475.

Aydin R, Pariza MW \& Cook ME (2001) Olive oil prevents the adverse effects of dietary conjugated linoleic acid on chick hatchability and egg quality. J Nutr 131, 800-806.

Ayerza R \& Coates W (2001) Omega-3 enriched eggs: The influence of dietary $\alpha$-linolenic acid fatty acid source on egg production and composition. Can J Anim Sci 81, 355-362.

Baumgard LH, Sangster JK \& Bauman DE (2001) Milk fat synthesis in dairy cows is progressively reduced by increasing supplemental amounts of trans-10, cis-12 conjugated linoleic acid (CLA). J Nutr 131, 1764-1769.

Belury MA \& Kempa-Steczko A (1997) Conjugated linoleic acid modulates hepatic lipid composition in mice. Lipids 32 , 199-204.

Botsoglou NA, Yannakopoulous AL, Fletours DJ, TserveniGoussi AS \& Psomas IE (1998) Yolk fatty acid composition and cholesterol content in response to level and form of dietary flaxseed. J Agric Food Chem 46, 4652-4656.

Bretillon L, Chardigny JM, Gregoire S, Berdeaux O \& Sebedio JL (1999) Effect of conjugated linoleic acid isomers on the hepatic microsomal desaturation activities in vitro. Lipids 34, 965-969.

Chamruspollert M \& Sell JL (1999) Transfer of dietary conjugated linoleic acid to egg yolks of chickens. Poult Sci 78, $1138-1150$.

Cook HW (1991) Fatty acid desaturation and chain elongation in eucaryotes. In Biochemistry of Lipids, Lipoproteins and Membranes, pp. 141-169 [DE Vance and J Vance, editors]. New York, NY: Elsevier.

Dhiman TR, Anand GR, Satter LD \& Pariza MW (1999) Conjugated linoleic acid content of milk from cows fed different diets. J Dairy Sci 82, 2146-2156.

Du M, Ahn DU \& Sell JL (1999) Effect of dietary conjugated linoleic acid on the composition of egg yolk lipids. Poult Sci 78, 1639-1645.

Du M, Ahn DU \& Sell JL (2000) Effects of conjugated linoleic acid and linoleic:linolenic acid ratio on polyunsaturated fatty acid status in laying hens. Poult Sci 79, 1749-1756.

Duncan DB (1955) Multiple range and multiple $F$ tests. Biometrics 11, 1-42.

Folch J, Lees M \& Sloane-Stanley GH (1957) A simple method for the isolation and purification of total lipides from animal tissues. J Biol Chem 226, 479-509.

Fritche J \& Steinhart H (1998) Analysis, occurrence, and physiological properties of trans fatty acids (TFA) with particular emphasis on conjugated linoleic acid isomers (CLA)-a review. Fett/Lipid 100, 190-210.

Goodridge J, Ingalls JR \& Crow GH (2001) Transfer of omega-3 linolenic acid and linoleic acid to milk fat from flaxseed or 
Linola protected with formaldehyde. Can J Anim Sci 81, 525-532.

Ip C, Banni S, Angioni E, Carta G, McGinley J, Thompson HJ, Barbano D \& Bauman D (1999) Conjugated linoleic acidenriched butter fat alters mammary gland morphogenesis and reduces cancer risk in rats. $J$ Nutr 129, 2135-2142.

Jones S, Ma DWL, Robinson FE, Field CJ \& Clandinin MT (2000) Isomers of conjugated linoleic acid (CLA) are incorporated into egg yolk lipids by CLA-fed laying hens. J Nutr 130, 202-205.

Joo ST, Lee JI, Ha YL \& Park GB (2002) Effects of conjugated linoleic acid on fatty acid composition, lipid oxidation, color, and water-holding capacity of pork loin. J Anim Sci 80, $108-112$.

Kelly MR, Berry JR, Dwyer DA, Griinari JM, Chouinard PY, Van Amburgh ME \& Bauman D (1998) Dietary fatty acid sources affect conjugated linoleic acid concentrations in milk from lactating dairy cows. $J$ Nutr 128, 881-885.

Kowalski ZM, Pisulewski PM \& Spanghero M (1999) Effects of calcium soaps of rapeseed fatty acids and protected methionine on milk yield and composition in dairy cows. J Dairy Res $\mathbf{6 6}$, 475-487.

Lawson RE, Moss AR \& Givens DI (2001) The role of dairy products in supplying linoleic acid to man's diet: a review. Nutr Res Rev 14, 153-172.

Lee KN, Pariza MW \& Ntambi JM (1998) Conjugated linoleic acid decreases hepatic stearoyl-CoA desaturase mRNA expression. Biochem Biophys Res Commun 248, 817-821.

Leskanich CO \& Noble RC (1997) Manipulation of the n-3 polyunsaturated fatty acids composition of avian eggs and meat. World's Poultry Sci J 53, 155-183.

Lewis NM, Seburg S \& Flanagan NL (2000) Enriched eggs as a source of n-3 polyunsaturated fatty acids for humans. Poult Sci 79, 971-974.

Mantzioris E, Cleland LG, Gibson RA, Neuman MA, Demasi M \& James MJ (2000) Biochemical effects of a diet containing foods enriched with n-3 fatty acids. Am J Clin Nutr 72, 42-48.

Matthews KR, Homer DB, Thies F \& Calder PC (2000) Effect of whole linseed (Linum usitatissimum) in the diet of finishing pigs on growth performance and on the quality and fatty acid composition of various tissues. Br J Nutr 83, 637-643.

Morrison WR \& Smith LM (1964) Preparation of fatty acid methyl esters and dimethylacetals from lipids with boron fluoride-methanol. J Lipid Res 5, 600-608.

Noakes M, Nestel PJ \& Clifton PM (1996) Modifying the fatty acid profile of dairy products through feedlot technology lowers plasma cholesterol in humans consuming the products. Am J Clin Nutr 63, 42-46.

Noone EJ, Roche HM, Nugent AP \& Gibney MJ (2002) The effect of dietary supplementation using isomeric blends of conjugated linoleic acid on lipid metabolism in healthy human subjects. Br J Nutr 88, 243-251.
Park Y, Albright KJ, Storkson JM, Liu W, Cook ME \& Pariza MW (1999) Changes in body composition during feeding and withdrawal of dietary conjugated linoleic acid. Lipids 34, 243-248.

Raes K, Huyghebaert G, De Smet S, Nollet L, Arnouts S \& Demeyer D (2002) The deposition of conjugated linoleic acid in eggs of laying hens fed diets varying in fat level and fatty acid profile. J Nutr 132, 182-189.

Ramsay TG, Evock-Clover CM, Steele NC \& Azain MJ (2001) Dietary conjugated linoleic acid alters fatty acid composition of pig skeletal muscle and fat. J Anim Sci 79, 2152-2161.

Roche HM, Noone E, Nugent A \& Gibney MJ (2001) Conjugated linoleic acid: a novel therapetic agent? Nutr Res Rev 14, $173-187$.

Sandström B, Bügel S, Lauridsen C, Nielsen F, Jensen C \& Skibsted LH (2000) Cholesterol-lowering potential in human subjects of fat from pigs fed rapeseed oil. Br J Nutr 84, $143-150$.

Schaefer RJ (2002) Lipoproteins, nutrition, and heart disease Am J Clin Nutr 75, 191-212.

Scollan ND, Choi N-J, Kurt E, Fisher AV, Enser M \& Wood JD (2001) Manipulating the fatty acid composition of muscle and adipose tissue in beef cattle. Br J Nutr 85, 115-124.

Simon O, Männer K, Schäfer K, Sagredos A \& Eder K (2000) Effects of conjugated linoleic acid on protein to fat proportions, fatty acids, and plasma lipids. Eur J Lipid Sci Technol 102, 402-410.

Stewart JW, Kaplan ML \& Beitz DC (2001) Pork with a high content of polyunsaturated fatty acids lowers LDL cholesterol in women. Am J Clin Nutr 74, 179-187.

Surai PF \& Sparks NHC (2001) Designer eggs: from improvement of egg composition to functional food. Trends Food Sci Technol 12, 7-16.

Szymczyk B \& Pisulewski PM (2002) Feeding conjugated linoleic acid-enriched egg yolks alters serum lipid profile in adult rats. Ann Anim Sci 2, 171-178.

Szymczyk B, Pisulewski PM, Hanczakowski P \& Szczurek W (2000) The effects of feeding conjugated linoleic (CLA) on rat growth, serum lipoproteins and subsequent lipid composition of selected rat tissues. J Sci Food Agric 80, $1553-1558$

Szymczyk B, Pisulewski PM, Hanczakowski P \& Szczurek W (2001) Effects of conjugated linoleic acid on growth performance, feed conversion efficiency, and subsequent carcass quality in broiler chickens. Br J Nutr 85, 465-473.

Van Elswyk ME (1997) Comparison of $n-3$ fatty acid sources in laying hen rations for improvement of whole egg nutritional quality: a review. Br J Nutr 78, Suppl. 1, S61-S69.

Wiseman J \& Agunbiade JA (1998) The influence of changes in dietary fat and oils on fatty acid profiles of carcass fat in finishing pigs. Livestock Prod Sci 54, 217-227. 